\title{
Consequences of Urban Living: Urbanization and Ground Beetles
}

\author{
Tibor Magura $^{1}$ (D) Gábor L. Lövei ${ }^{2}$ (D)
}

Accepted: 31 August 2020 / Published online: 12 September 2020

(C) The Author(s) 2020

\begin{abstract}
Purpose of Review Urbanization is increasing worldwide, transforming environmental and habitat parameters, and causing adverse effects on organisms living in urban habitats. Urban studies on ground beetles are exponentially increasing and cover all levels of biological organization. Still, to date, there is no comprehensive paper reviewing the impacts of urbanization on ground beetles at different levels of biological organization.

Recent Findings At the population level, urbanization induces changes in the morphological characters, including fluctuating asymmetry, physiological condition, behavioral characteristics, seasonal activity, population size, and genetic diversity in ground beetles. Different species groups (habitat specialists vs. generalists, large vs. small-sized species, poor vs. good dispersers, predators vs. herbivores) respond differently to urbanization. Community-level changes associated with urbanization include the abundance, taxonomic as well as functional diversity, community assembly mechanisms, composition, and body size distribution. At the ecosystem level, urbanization influences several ecosystem processes and functions related to ground beetles, but data are only available concerning the edge effect and predation.

Summary Urbanization has a considerable effect at various levels of the biological organization on ground beetles living in urban habitats. However, results - especially at the population and community levels - show inconsistent patterns. This discrepancy may result from individual responses and different sensitivity of species to urbanization, suggesting the importance of individualistic and functional approach in future urban studies. To preserve a rich carabid diversity in urban areas, multi-scale greenspace planning and management schemes are needed; these will also ensure both the recreational and the diversitypreserving function of urban green spaces.
\end{abstract}

Keywords Carabids $\cdot$ Environmental changes $\cdot$ Functional groups $\cdot$ Population $\cdot$ Species $\cdot$ Urban biodiversity

\section{Introduction}

The earliest urban settlements were developed in Mesopotamia, Egypt, and eastern Asia, but urbanization is also one of the basic features of European civilization. Starting in south-eastern Europe from approximately 700 BC, the process of urbanization gradually spread to the entire

This article is part of the Topical Collection on Urban Landscape Ecology

Tibor Magura

maguratibor@gmail.com

Gábor L. Lövei

gabor.lovei@agro.au.dk

1 Department of Ecology, University of Debrecen, Egyetem sq. 1, Debrecen H-4032, Hungary

2 Department of Agroecology, Aarhus University, Flakkebjerg Research Centre, DK-4200 Slagelse, Denmark continent [1]. This process means the spatial expansion of urban land use, the growth of urban population, and the spread of urban way of life [2]. Urbanization has since spread worldwide; today, $55 \%$ of the human population lives in urbanized areas, and this trend is predicted to continue [1, 3]. Urbanization as a main form of anthropogenic activities is an increasingly important force shaping the original, natural environment by creating patchworks of modified land types. Therefore, urbanization and the associated environmental impacts have been and continue to be one of the greatest challenges facing humankind [4].

Urban areas also have profoundly changed environmental conditions. One of these is the increasing proportion of artificial surfaces (sidewalks, roads, buildings). These surfaces alter wind and water currents, influencing the microclimate [5]. An urban "heat island" forms, where the mean daily air (and consequently also soil [6]) temperatures within cities becomes $1-5^{\circ} \mathrm{C}$ warmer than in the surrounding, undeveloped area [7]. 
As a result of global warming, this climate-related effect will be even more accentuated, creating greater problems [8]. Other environmental parameters (e.g., humidity [9]) and soil properties (compactness, soil $\mathrm{pH}$ ) are also changed by urbanization [10]. Furthermore, urbanization increases the deposition of heavy metals and other pollutants [11], as well as of nutrients [12].

Modifications in environmental parameters in urban habitats generate stresses on living organisms, resulting in adverse effects on their activity pattern, spatial distribution, phenology, productivity, and biotic interactions [2], with subsequent modifications of the structure and composition of biotic communities [13, 14]. In addition, the (usually combined) loss, fragmentation and modification of natural habitats, and the appearance of exotic, invasive, and generalist species strengthen the effects of urbanization on living organisms and their communities $[13,15]$. Consequent to these changes, the ecosystem functions provided by them are also affected [2]. For example, decomposition and mineralization rates are usually lower in urban than non-urban habitats [6]. Similarly, pollination efficiency is often lower in urban environments than non-urbanized ones [16].

Most research on the impacts of urbanization was performed on birds [17, 18], plants [19, 20], and terrestrial arthropods $[2,21,22 \cdot]$. Of the terrestrial arthropods, ground beetles (Coleoptera: Carabidae) have been a particularly popular subject for urbanization studies [23-25]. Ground beetles are highly appropriate objects for such studies because their taxonomy and ecology are well known, are common in most terrestrial habitats, and can easily be collected using standard methods [26]. All these features make them a suitable indicator group of human-caused disturbance and environmental quality [27]. Urban studies on ground beetles date back to the 1980s (e.g., [28]). The number of papers has rapidly increased since the early 2000s (Fig. 1), likely due to international projects examining the effects of human-caused disturbance on ecosystems (e.g., ILTER [29], GLOBENET [30], PREDICTS [31]). Among these, the GLOBENET (Global Network for Monitoring Landscape Change) project has a key role, as it was established to assess and compare landscape changes related to human activities on a global scale, using a standard urbanization gradient approach, a standardized field methodology (pitfall trapping), and a single group of invertebrates, the ground beetles [30]. The GLOBENET project used the gradient approach [10], but was restricted to examine the impact of urbanization on forested habitats. Consequently, when not otherwise specified, under "urban habitats" we mean "forest fragments in urban environments" in this review. Published studies document various and often profound impacts on ground beetles at various levels of biological organization [24, 25, 32]. To date, however, there is no review paper summarizing the effects of urbanization on ground beetles from the population level, through the (sub)community level

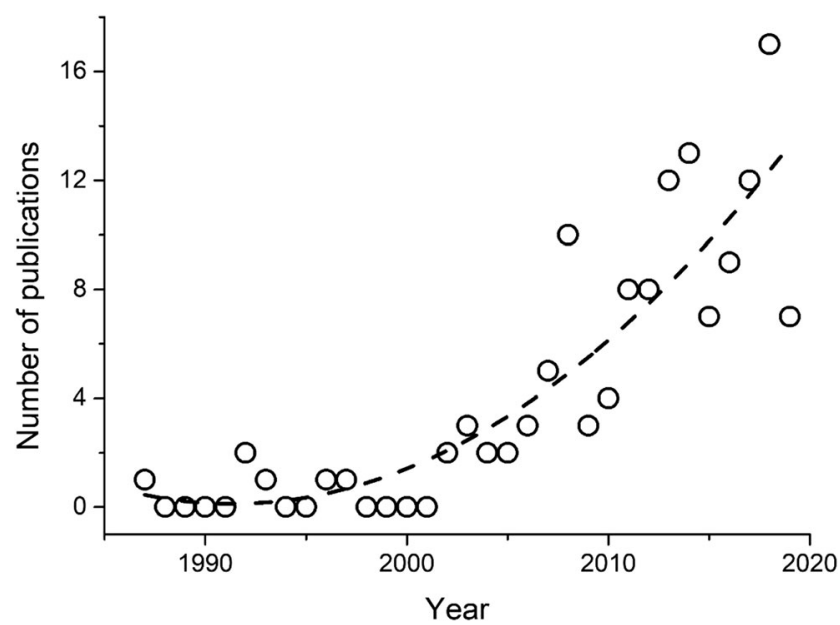

Fig. 1 The number of published urban studies on ground beetles per year for the period 1975-2020. The literature search was performed on 4 April 2020 in Web of Science, using the following search terms: TOPIC $=$ (urbanisation OR urbanization) AND TOPIC $=($ carabid $*)$. The fitted second order polynomial curve shows a significant relationship $\left(F_{2,30}=52.33, p<0.001, R^{2}=0.76\right)$

to the ecosystem level. In the present paper, reviewing 139 published urban studies on ground beetles (Fig. 1), we aim to fill this gap.

\section{Effects of Urbanization at the Population Level}

Environmental and habitat changes, as well as disturbances accompanying urbanization (e.g., "heat island" effect, pollution, poor habitat quality, fragmented and isolated habitat patches) are manifested in morphological characteristics of members of urban populations [33].

Of the morphological traits, body size is perhaps the most important one since it is correlated with many aspects of life history (reproduction rate, dispersal, development time) but also has a significant impact on resource use and ecological interactions [34]. Gray's increasing disturbance hypothesis [35] predicts that mean body size should decrease from less to more disturbed habitats, in the present context from rural to urban areas. Data are equivocal; changes in ground beetle body size along urbanization gradients do not seem to show a consistent pattern $[36,37]$. Of the four species studied in and around Hamburg, Germany, only the size of adult Carabus nemoralis decreased significantly from the rural area toward the center of the city [36]. Other studies showed even the opposite trend, as adult body size in Carabus granulatus [37], Pterostichus madidus, and Abax parallelepipedus increased significantly with advancing urbanization [38].

Examining morphological traits of four common European ground beetle species (A. parallelepipedus, Carabus scheidleri, Carabus violaceus, and Pterostichus 
oblongopunctatus) along an urbanization gradient in and around the cities of Vienna (Austria) and Debrecen (Hungary), significant differences in the parameters of antennomers, the maxillary palpus, the labial palpus, and the length of the tibia and the elytra were found among rural, suburban, and urban populations [39]. Results, however, seem to be inconsistent, as some measured parameters were greater in urban sites compared with rural ones (greatest length of the tibia of $A$. parallelepipedus individuals and greatest length of the second segment of the antenna and the greatest width of the third palpomer of the maxillary palpus of C. scheidleri was measured in urban specimens), while $P$. oblongopunctatus showed the opposite tendency (greatest length of the third segment of the antenna was in rural individuals) [39].

Several morphological traits are symmetrical. Environmental stress disturbs the developmental stability of an organism, causing deviations from symmetrical growth [40]. The measurement of fluctuating asymmetry (FA) quantifies random and non-directional deviations from perfect bilateral symmetry and is regarded as an effective indicator of environmental quality or stress $[41,42]$. Along gradients from rural forests to woodlots in the center of Hamburg (Germany), FA (measured as the difference between the length of the right and the left elytrum) of ground beetle species increased toward the city center, indicating a negative effect of urbanization [36]. Similarly, significant asymmetry was found in the lengths and widths of the third palpomer of the right and left maxillary palpus and the widths of the second palpomer of the right and left labial palpus for populations of four species (A. parallelepipedus, C. scheidleri, C. violaceus, and $P$. oblongopunctatus) along urbanization gradients of the cities of Vienna (Austria) and Debrecen (Hungary) [39]. A study along a Danish urbanization gradient, measuring eight metric (length of the second and third antennal segments, elytral length, length of the first tarsus segment, length of the first and second tibiae, length of the proximal and distal spines on the first femurs) and one meristic (the number of spines on the second tibiae) traits of three species (C. nemoralis, Nebria brevicollis, and Pterostichus melanarius), however, showed inconsistent results [43]. This discrepancy further deepens the debate over the applicability of FA to assess environmental quality or stress [42].

Urbanization-induced environmental stress can also influence the body condition of individuals, either directly by changes in behavior patterns (e.g., foraging success) or indirectly through morphological changes (e.g., changes in body size). Body condition could be a useful signal to characterize environmental quality, as it provides a flexible feedback about the physiological state of the individual [44]. Using a condition index, where the body mass is regressed on body size, and the residuals provide an estimate of condition, Elek et al. [44] showed that urban individuals of $C$. nemoralis had significantly the best condition. The condition index for $N$. brevicollis, however, was not significantly different between the rural and urban habitats. Contrarily, P. melanarius showed significantly better condition in rural forests than in the urban forest fragments [44].

Individual physiological condition can also affect the resistance to infections and pathogens. Studies investigating rural and urban habitats simultaneously, however, are few, so there is a gap in our knowledge about this phenomenon. A study about infection on ground beetles by phoretic mites found that the prevalence, mean abundance, mean, and median intensity of phoretic mites on $C$. violaceus were significantly higher in rural forests compared with urban forest fragments [45]. The studied phoretic mite species use beetles only for transfer and do not infect and damage them. Thus, the decrease of the prevalence and mean intensity of these mites in urban habitats indicates the effect of urbanization on mites, rather than the impact of urbanization on beetle resistance to infections.

Urbanization can force individuals to change their behavior in response to changing environmental conditions. Some behavioral traits, such as high exploration and high risk-taking, may help to cope with altered conditions and/or for colonizing urban habitats [46••]. Testing exploratory and risk-taking behavior of ground beetles living in differently urbanized forests in Hamburg, Germany, Schuett et al. [46••] found that individuals of urban populations of all four studied species (A. parallelepipedus, P. oblongopunctatus, C. nemoralis, $N$. brevicollis) showed a generally higher level of exploratory behavior compared with individuals from rural populations. This pattern, however, was clear only in one of the two years of field study, raising questions about the consistency of individual behavior.

Environmental pollution accompanied by urbanization may cause serious damage to ecosystems and their inhabiting organisms. Toxic elements can accumulate in soil and leaf tissue as well as in consumers and decomposers through the food chain [11]. Concentrations of toxic elements in leaf litter differed between rural and urban habitats in Debrecen, Hungary, indicating a potential for higher accumulation in urban decomposers. Still, individuals of two generalist predatory ground beetles ( $C$. violaceus and $P$. oblongopunctatus) that also feed on decomposers showed no significant difference in toxic element concentrations according to urbanization level [11].

Changes in microclimate associated with urbanization (e.g., the urban "heat island" effect) could influence the activity start or change the timing of activity peaks of urban populations. Studies on seasonality of ground beetles along a Danish urbanization gradient identified two main groups $[47,48]$. The first one includes species whose activity profiles did not differ between rural and urban habitats ( $N$. brevicollis with bimodal and $P$. melanarius with unimodal activity pattern). The second group consists of species whose activity pattern varied remarkably among the differently urbanized 
habitats. Adults of $C$. nemoralis appeared about 4 weeks earlier in the urban forest patches than the rural ones and showed a steep autumn activity increase in the rural habitats [47, 48].

Environmental changes caused by urbanization can have positive, negative, and neutral effects on population sizes [49]. Based on a meta-analysis, many species show consistent responses across the urbanization gradient and might therefore be considered urban avoiders or urban exploiters, while numerous others are relatively insensitive to urbanization [25]. Accordingly, the number of individuals in several urban populations can be significantly lower (Cychrus caraboides in southern Finland [50]; Carabus convexus, Ophonus nitidulus, and $P$. oblongopunctatus in a Hungarian city [51]), higher (Pterostichus mannerheimii and P. oblongopunctatus in Yekaterinburg, Russia [52]; Amara convexior in Berlin, Germany [53] and Debrecen, Hungary [51]), or about the same (Pterostichus magus in a Russian megalopolis [52]; Amara saphyrea, Anisodactylus nemorivagus, Bembidion lampros, Harpalus luteicornis, Notiophilus rufipes, P. melanarius, Pterostichus niger, and Stomis pumicatus in eastern Hungary [51]) than their equivalent rural populations.

Fragmentation and isolation as well as lower habitat quality of remnant urban habitat patches may lead to increased genetic differentiation as a result of founder effects, genetic drift, demographic bottlenecks, and local selection [54]. Examining genetic diversity and differentiation of two ground beetle species in forests along rural-urban gradients in two cities (Brussels and Birmingham), based on allozymes, Desender et al. [55] found that P. madidus populations in Birmingham expressed significantly higher levels of heterozygosity in smaller urban and suburban forest patches than in rural forests. By contrast, the allelic richness of A. parallelepipedus populations in Birmingham, UK, appeared to be unrelated to the degree of urbanization surrounding the forest site [55].

Although, as shown, the impact of urbanization can be detected at the population level in ground beetles, these findings are inconsistent (Table 1). It seems that different species, and even the same species in different localities, could show conflicting responses to urbanization, currently preventing to draw reliable generalizations on population-level responses to urbanization in ground beetles.

\section{Effects of Urbanization at the Subcommunity/Species Group Level}

Inconsistent population-level results may be due not only to the diverse responses of ground beetle individuals to urbanization but also to different sensitivity of species to anthropogenic environmental changes. Some groups (habitat specialist species, large-sized species, species with limited dispersal power) may have narrower tolerance limits and would consequently suffer, while others (generalist and matrix species, small-sized species, good dispersers) can benefit from the changes in habitats and environmental conditions caused by urbanization. Therefore, urban studies could benefit from an approach centered on species groups, to evaluate the real effects of urbanization $[25,32]$.

Native, habitat specialist species generally are more abundant in rural than in urban forests [56-58] or grasslands [59]. Contrarily, species from the matrix, such as open-habitat species in forest patches, are more numerous in urbanized than rural habitats $[56,58]$. Habitat generalist species show various patterns, as their abundance may be higher [57, 58], lower [60], or similar [61] in rural than in urban ones. Results from syntheses of published data support the assumption that species with the same habitat affinity show consistent abundance patterns along urbanization gradients: habitat specialist species tend to be more common in rural zones, while matrix species (e.g., open-habitat species in forested habitats) dominate in the urban areas [24, 25].

Body size may be an important predictor of sensitivity to environmental hazard. Large-bodied species may be more vulnerable to disturbance than smaller ones, possibly because of their lower reproductive output and dispersal power [62]. Therefore, species belonging to different size classes may be differently impacted by urbanization. Urbanization indeed has a negative effect on the abundance of large-sized (> $12.51 \mathrm{~mm}$ ) ground beetles [24, 25, 38, 60,63, 64], while there are no uniform patterns regarding medium- and small-sized species [25, 63, 65].

Dispersal power, connected to the presence or absence of flight ability, may also be an important trait in changing environments. Species with long-winged or wing-dimorphic individuals may be less prone to decline than those that are exclusively short winged [62]. Indeed, urban habitats are usually characterized by the dominance of good disperser (longwinged and wing-dimorphic) species [65], whereas poor disperser (short-winged) species are more common in rural habitats $[24,25,38]$.

Another important feature under strong impact by urbanization is the feeding habit. In urban sites, changes in environmental conditions, pollution, and invasion of exotic plants have potential impacts on food resources of ground-dwelling arthropods, influencing their abundance either directly or indirectly [22•]. Zoophagous (carnivorous or predatory) species, potential indicators of natural ecosystems, are regarded as the most sensitive to urbanization-driven disturbance [66]. Results from an extensive meta-analysis clearly show that urbanization has a negative effect on the abundance of predatory species [25].

Combining habitat specialization, body size, and feeding habit may be a particularly powerful indicator of urbanization. In urban habitats, large-bodied forest specialists may completely disappear, while small-sized forest specialists and medium-sized habitat generalists show higher abundance 
Table 1 Changes in characteristics of ground beetles with advancing urbanization at the population level

\begin{tabular}{|c|c|c|}
\hline Characteristic, species & Detected change & Reference number* \\
\hline \multicolumn{3}{|l|}{ Genetic structure } \\
\hline Heterozygosity in Pterostichus madidus & Higher & 55 \\
\hline Allelic richness of Abax parallelepipedus & No change & 55 \\
\hline \multicolumn{3}{|l|}{ Body size } \\
\hline Abax parallelepipedus & Increased & 38 \\
\hline Calathus fuscipes & No change & 36 \\
\hline Carabus granulatus & Increased & 37 \\
\hline Carabus nemoralis & Decreased & 36 \\
\hline Leistus rufomarginatus & No change & 36 \\
\hline Nebria brevicollis & No change & 36,38 \\
\hline Pterostichus madidus & Increased & 38 \\
\hline \multicolumn{3}{|l|}{ Morphological parameters } \\
\hline Abax parallelepipedus, tibial length & Increased & 39 \\
\hline Carabus scheidleri, length of 2 nd antennal segment & Increased & 39 \\
\hline Carabus scheidleri, width of 3rd palpomer of the maxillary palpus & Increased & 39 \\
\hline Pterostichus oblongopunctatus, length of 3 rd antennal segment & Decreased & 39 \\
\hline Pterostichus oblongopunctatus, left/right difference in elytral length & Increased & 36 \\
\hline Carabus nemoralis, left/right difference in eight metric and one meristic traits & No change & 43 \\
\hline Nebria brevicollis, left/right difference in eight metric and one meristic traits & No change & 43 \\
\hline Pterostichus melanarius, left/right difference in eight metric and one meristic traits & No change & 43 \\
\hline \multicolumn{3}{|l|}{ Condition } \\
\hline Carabus nemoralis & Better & 44 \\
\hline Nebria brevicollis & No change & 44 \\
\hline Pterostichus melanarius & Worse & 44 \\
\hline \multicolumn{3}{|l|}{ Infection } \\
\hline Carabus violaceus, infection by phoretic mites & Lower & 45 \\
\hline \multicolumn{3}{|l|}{ Exploratory behavior } \\
\hline Abax parallelepipedus & Higher & 46 \\
\hline Carabus nemoralis & Higher & 46 \\
\hline Nebria brevicollis & Higher & 46 \\
\hline Pterostichus oblongopunctatus & Higher & 46 \\
\hline \multicolumn{3}{|l|}{ Toxic element concentrations } \\
\hline Carabus violaceus & No change & 11 \\
\hline Pterostichus oblongopunctatus & No change & 11 \\
\hline \multicolumn{3}{|l|}{ Seasonal activity } \\
\hline Carabus nemoralis & Earlier emergence & 47,48 \\
\hline Nebria brevicollis & No change & 47,48 \\
\hline Pterostichus melanarius & No change & 47,48 \\
\hline \multicolumn{3}{|l|}{ Abundance } \\
\hline Carabus convexus & Lower & 25,51 \\
\hline Cychrus caraboides & Lower & 25,50 \\
\hline Ophonus nitidulus & Lower & 51 \\
\hline Pterostichus niger & Lower & 25 \\
\hline Pterostichus oblongopunctatus & Lower & 25,51 \\
\hline Stomis pumicatus & Lower & 25 \\
\hline Anisodactylus nemorivagus & No change & 51 \\
\hline Amara saphyrea & No change & 51 \\
\hline Bembidion lampros & No change & 25,51 \\
\hline Harpalus luteicornis & No change & 25,51 \\
\hline Notiophilus rufipes & No change & 25,51 \\
\hline Pterostichus magus & No change & 52 \\
\hline Pterostichus melanarius & No change & 25,51 \\
\hline Pterostichus niger & No change & 51 \\
\hline Stomis pumicatus & No change & 51 \\
\hline Amara convexior & Higher & $25,51,53$ \\
\hline Pterostichus mannerheimii & Higher & 52 \\
\hline Pterostichus oblongopunctatus & Higher & 52 \\
\hline
\end{tabular}

*See the reference list

[67]. In contrast, rural habitats are characterized by large- and medium-sized forest specialists and small-sized habitat generalists [67]. Moreover, macropterous, good disperser open- habitat species (e.g., Amara brunnea, Leistus ferrugineus, and Pterostichus strenuus) are relatively more abundant in urban forest patches than in rural forested areas [68]. By 
synthesizing the results of individual studies, it is clear that urbanization has the most detrimental effect on the abundance of large-sized, predatory, or omnivorous forest-specialist species [25].

Species richness or diversity of the sub-assemblages of species with different habitat affinity show fairly uniform patterns along urbanization gradients, although there is a study reporting no trends [61]. The diversity of forest specialist species is higher in rural forests than in urban fragments in both Northern [63], Western [38], and Eastern Europe [58, 69, 70], as well as North America [56]. A recent study, using ground beetle data from nine countries and the Rényi diversity ordering method [71], reported a robust relationship in the diversity of the forest specialist species: at all locations, the subassemblages of these species were unequivocally more diverse in the rural than the urban habitats. [32]. The diversity of open-habitat species increases from the rural forest toward the urban forest patches $[56,58,63,70]$.

Ground beetles show a generally consistent pattern along urbanization gradients at the subcommunity/species group level (Table 2). Some groups of species (habitat specialist, large-sized, carnivorous species with limited dispersal power) seem to suffer, while others (small-sized, omnivorous, or herbivorous, good disperser matrix species) can benefit from changes in environmental and habitat conditions accompanying urbanization.

\section{Effects of Urbanization at the Community Level}

Several hypotheses are formulated to describe the impacts of disturbance on biotic communities. The intermediate disturbance hypothesis [72] predicts an increase in diversity at intermediate levels of disturbance, in moderately disturbed sites. The increasing disturbance hypothesis [35], on the other hand, forecasts a decrease in diversity as the level of disturbance increases. For ground beetles, only one study confirmed the intermediate disturbance hypothesis, as overall carabid abundance was significantly the highest at the moderately disturbed suburban sites [73]. Other studies generally showed a decrease in overall abundance from the rural habitats toward the urban ones, be that in Asia [67] or in Europe [57, 58, 70, $74,75]$. In contrast, ground beetle abundance was significantly lower in rural habitats than in urban ones in a Russian megalopolis, Yekaterinburg [52, 76]. Furthermore, overall ground beetle abundance was not significantly different between rural and urban sites in Bulgaria [75], France [61], Finland [60], and Canada [75]. The studied Canadian city (Edmonton), however, was characterized by a numerical dominance of exotic ground beetles, and when these were included in the analysis, overall abundance increased significantly from rural to urban sites [75]. A meta-analysis of 18 studies concluded that the total number of ground beetles in a community did not differ between rural and urban sites [25].

Trends in overall species richness or species diversity are quite similar to those of abundance. Only one study showed elevated ground beetle diversity in suburban sites, conforming to the predictions of the intermediate disturbance hypothesis [73]. Species richness or diversity of ground beetles decreased from rural to urban areas in Birmingham, UK [38], Brussels, Belgium [57], Halle, Germany [77], Hamburg, Germany [36], Helsinki, Finland [68, 75], Hiroshima, Japan [67], Paris, France [74], and Rennes, France [78]. In Edmonton (Canada), the mean species richness also significantly decreased from rural to urban sites; however, with the inclusion of introduced species, the difference became non-significant [75]. In other data sets from Debrecen, Hungary [58, 70], Helsinki, Finland [60], Pacé, France [61], Sofia, Bulgaria [75], and Sorø, Denmark [63], there were no significant differences in species richness between the rural and urban habitats. Moreover, in General Pueyrredón district (Argentina) [65], Sorø (Denmark) [79], and Yekaterinburg (Russia) [52, 76], there were significantly fewer species or lower diversity in the rural sites compared with the urban ones. Comparing ground beetle data from nine locations by diversity ordering methods, Magura et al. [32] found that overall diversity showed inconsistent trends by urbanization intensity. In contrast, a meta-analysis including data sets from 15 localities found that urbanization had a negative effect on ground beetle species richness [25]. Overall, it seems that abundance or species richness is not an entirely suitable parameter to indicate the impacts of urbanization on ground beetles. Even within a taxonomic group, different sets of species may show differing tolerances or affinities toward urbanization-driven environmental changes. Thus, due to the often conflicting responses of species groups to urbanization, the direction of changes of overall abundance and species richness may be unpredictable.

Functional diversity is a key component of biodiversity, as it is a good predictor of the functioning, stability, and resilience of both communities and ecosystems [80, 81]. Yet, comparisons of functional diversity across differently urbanized habitats are rare in urbanization studies of ground beetles. A study in Zurich, Switzerland found a significant decrease in ground beetle functional diversity from rural to urban areas, indicating the filtering process that preferred species preadapted to urban conditions [82••].

The knowledge of which species are filtered out from urban habitats is important to understand community assembly and to develop management actions to cope with human impacts during urban development [82••]. In the urban green spaces of Zurich (Switzerland), strong environmental filtering from a regional to urban species pool was identified, leading to the selection of lowland-preferring, winged, drought-tolerant species with broad feeding preferences (omnivores) [82・•]. Although xerophilic species also dominated in the city of 
Table 2 Changes in abundance and diversity of ground beetles with advancing urbanization at the subcommunity/species-group level

\begin{tabular}{|c|c|c|}
\hline Characteristic, group & Detected change & Reference number* \\
\hline \multicolumn{3}{|l|}{ Abundance } \\
\hline Native, habitat specialist species & Lower & $24,25,56,57,58,59$ \\
\hline Matrix species & Higher & $24,25,56,58$ \\
\hline Habitat generalist species & Lower & 60 \\
\hline Habitat generalist species & No change & 61 \\
\hline Habitat generalist species & Higher & 57,58 \\
\hline Species of large body size & Lower & $24,25,38,60,63,64$ \\
\hline Good disperser (long-winged and wing-dimorphic) species & Higher & 65 \\
\hline Open-habitat-preferring, good disperser (macropterous) species & Higher & 68 \\
\hline Poor disperser (short-winged) species & Lower & $24,25,38$ \\
\hline Zoophagous (carnivorous or predatory) species & Lower & 25,66 \\
\hline Forest specialist species of large body size & Lower & 67 \\
\hline Forest specialist, predatory or omnivorous species of large body size & Lower & 25 \\
\hline Forest specialist species of large and medium body size & Lower & 67 \\
\hline Forest specialist species of small body size & Higher & 67 \\
\hline Habitat generalist species of medium body size & Higher & 67 \\
\hline Habitat generalist species of small body size & Lower & 67 \\
\hline \multicolumn{3}{|l|}{ Diversity } \\
\hline Forest specialist species & Lower & $32,38,56,58,63,69,70$ \\
\hline Open-habitat species & Higher & $56,58,63,70$ \\
\hline
\end{tabular}

*See the reference list

Debrecen (Hungary), the co-occurring species were functionally and phylogenetically not different from the null model, indicating that urban communities there were assembled from the regional species pool by a stochastic (random) process [83••]. Irrespective of whether species with appropriate traits and tolerance limits for urban environments are assembled from the regional pool by deterministic or stochastic processes, urban ground beetle communities usually consist of species with tolerance of higher temperatures, with better dispersal capacities and broader habitat preferences compared with species from rural communities $[74,84 \bullet, 85,86,87]$. The species in urban habitats mostly originate from the surrounding matrix (agricultural areas, plantations, secondary habitats) mainly through immigration [88]. These shifts seem to fundamentally and consistently alter the species composition in urban habitats [24, 32]. Indeed, results from Asian [67, 89], European [38, 58, 63, 68, 73, 84•], and North-American [56] studies show that carabid community composition in urban habitats significantly differ from that of non-urbanized ones. This is, however, not always the case. One Finnish study did not show marked differences in community structure along the urbanization gradient [75], and ground beetles in Bulgaria and Canada did not separate into distinct rural and urban communities [75].
From the changes in species composition in urban habitats, it could be assumed that urbanization will homogenize the taxonomic composition of ground beetles and create similar communities in urban habitats [32]. However, this does not seem to be so. Analyzing species composition of rural and urban habitats from nine countries (north-western European, south-eastern European, and locations outside Europe), the urban communities were more similar to their local rural counterpart than urbanization stages were to each other within the given geographical region [32]. Urbanization therefore did not homogenize ground beetle communities, possibly indicating the influence of local matrix species. However, the immigration of matrix species into urban habitats seems to be unpredictable. Such stochastic species influx can lead to heterogeneous and locally different urban communities, preventing taxonomic homogenization and the assembly of "urban-specific" carabid communities [32].

Body size distribution can regulate biotic interactions, thus influencing ecological networks and functions [90•]. Higher ambient temperature causes increased metabolic costs in ectothermic organisms. Thus, it is expected that increased temperatures accompanied by urbanization (the urban heat island effect) will reshape body size distribution in communities, driving shifts to smaller body sizes [90•]. Results from 
Belgium [90•, 91], Bulgaria [75], the Czech Republic [28], Germany [92], Hungary [64, 70], Poland [93], Slovakia [28], and the UK [38] suggest a general trend that urban communities consist of smaller species than rural ones. A similar but only marginally significant trend was reported from Finland [75]. However, no significant changes in body size were detected in Canada [75] and Germany [36]. A recent study assumes that shifts to smaller body sizes in urban communities cannot be uniform since body sizes of immigrating species from the surrounding matrix into urbanized habitats are unpredictable. Moreover, these matrix species may be more tolerant of higher ambient temperatures, and therefore, the temperature-driven phenotypic change in size could be reduced or eliminated [94•]. Indeed, by re-analyzing data from 11 countries, there was no general trend toward reduced body size in carabid communities living in urbanized habitats [94•].

Stochastic processes (colonization and survival of matrix species, moreover the survival of habitat specialist species in urban environment) fundamentally determine the communitylevel responses of ground beetles to urbanization, making the direction of changes in community parameters (abundance, taxonomic and functional diversity) unpredictable (Table 3).

\section{Effects of Urbanization at the Ecosystem Level}

In this context, all biotic interactions between communities, and ecological processes simultaneously influencing several communities, are interpreted as phenomena above the community level and are referred to as ecosystem-level processes. These include the loss of habitat, reduction of patch size, fragmentation, and isolation of remnant habitat patches in urban areas, which cause changes in abundance and spatial pattern of species, influencing the composition of communities. Changes at the population and/or community level can also force modifications in ecosystem processes and functions.

Organisms occurring in fragments are exposed to conditions similar to those in the surrounding matrix habitat. This so-called "edge effect" has a substantial impact at population, community, and ecosystem levels [95]. Management practices of urban habitats may alter the location and intensity of edge effects [96]. The abundance of forest specialist carabids was similar in edges maintained by natural processes and their interiors, while it was significantly lower in the edges than interiors of urban forest fragments [97, 98]. The filtering function of variously maintained edges is fundamentally different. For forest specialist species, edges maintained by natural processes are penetrable, allowing these species to enter and cross the edges. However, edges created by urbanization are impenetrable, blocking the emigration of forest specialists from the forest fragments, contributing to even higher isolation of these species [97, 98]. Similarly, the abundance of predatory ground beetles was higher in natural edges than their forest interiors, while no similar pattern was detected in edges sustained by urbanization. These results suggest that structural and environmental changes at the edges of urban forest fragments may have negative effects on ecosystem services like pest control [99].

Predation, with its community structuring effects, is one of the most important ecosystem processes [100]. Changes in habitat quality and the accompanying environmental conditions have serious impacts on predators. Predation pressure is lower in urban than rural habitats [101] even though this conclusion is mostly based on predation by vertebrates.

Table 3 Changes in characteristics of ground beetles with advancing urbanization at the community level

\begin{tabular}{lll}
\hline Characteristic & Detected change & Reference number* \\
\hline Abundance & Lower & $57,58,67,70,74,75$ \\
Abundance & No change & $25,60,61,75$ \\
Abundance & Higher & 52,76 \\
Species richness or diversity & Lower & $25,36,38,57,67,68,74,75,77,78$ \\
Species richness or diversity & No change & $58,60,61,63,70,75$ \\
Species richness or diversity & Higher & $52,65,76,79$ \\
Functional diversity & Lower & 82 \\
Community assembly & Became stochastic & 83 \\
Community composition & Became different & $38,56,58,63,67,68,73,84,89$ \\
Community composition & No change & 75 \\
Taxonomic homogenization & None & 32 \\
Community weighted mean body size & Decreased & $28,38,64,70,75,90,91,92,93,94$ \\
Community weighted mean body size & No change & $36,75,94$ \\
Community weighted mean body size & Increased & 94 \\
\hline
\end{tabular}

*See the reference list 
Table 4 Changes in ecosystem-level characteristics of ground beetles with advancing urbanization

\begin{tabular}{lll}
\hline Characteristic & Detected change & Reference number* \\
\hline Filter function of edges for forest specialist species & Got impermeable & 97 \\
Filter function of edges for predatory species & Got impermeable & 98 \\
Predation pressure & Lower & 101,102 \\
Predation pressure & No change & 102 \\
\hline
\end{tabular}

*See the reference list

Measuring predation pressure along an urbanization gradient in Denmark using artificial caterpillars, it was found that chewing insects, mostly ground beetles, showed higher predation pressure in rural forests compared with urban forest fragments [102]. Likewise, along a riverside urbanization gradient in Hungary, arthropod attacks on sentinel prey on tree trunks decreased from rural to urban habitats [103]. At ground level, however, predation pressure was not significantly different [103]. Apart from pest control, ground beetles are involved in other ecosystem services, such as weed control through seed predation [104], and scavenging [105], but there are no studies on these services in urban environments.

At the ecosystem level, so far only edge effects and predation pressure have been studied. Difference in the dispersal filter function of natural versus urbanization-generated edges is well documented. Predation pressure by invertebrate predators (mostly ground beetles) shows some trends to decrease as urbanization advances, but this is based on two studies only, and even within those, the trend is not unequivocal (Table 4).

\section{Preserving Ground Beetle (and Invertebrate) Diversity in Urban Areas}

Urban green areas not only have recreational importance but substantially contribute to the quality of urban life [106]. In addition, they provide suitable habitats for numerous species, increasing urban biodiversity [58, 63, 106]. The currently dominant intense urban habitat management, including frequent mowing, strong pruning, and removal of decaying wood, however, is one of the leading causes of homogenization and impoverishment of urban arthropod assemblages [107]. Abandoning these practices, and adopting a "soft" management such as practiced in Denmark, will have a positive effect not only on ground beetle diversity [63] but on other invertebrates as well. It is also worth remembering that ground beetle larvae are more sensitive to environmental (mainly soil) conditions than adults [26], and providing suitable developmental conditions for larvae will dampen density fluctuations and thus reduce population extinction in habitat fragments.

Comparing carabid assemblages under compact versus conventional urban planning forms in Western France showed the superiority of the compact design to preserve carabids: both the total abundance and the abundance of large species was significantly higher in the compact neighborhood design (with concentrated, higher housing density, but larger and more connected public green spaces and hedgerows) compared with the conventional design that had lower housing density, but less dense and more fragmented public green spaces and hedgerows [108]. High-density development over a small area (compact development) minimizes the impacts of a given human population on ground beetles also in Canada [109]. At the landscape scale, landscape composition and the configuration of natural areas are key issues for species survival in urban habitat fragments [110]. This requires the application of the metapopulation concept, and landscape-scale thinking, considering not only the maintenance and/or restoration of high quality source habitats but the conservation or creation of effective corridors or stepping stones promoting species dispersal between matrix habitats and urban fragments $[78,111,112]$.

This leads to the need of a holistic, multi-scale management and planning scheme to adequately conserve and restore biodiversity in urbanized areas [106]. At the habitat scale, conservation of existing urban green spaces $[59,77,113]$, reducing the intensity of management operations [53], switching to ecologically oriented management [59], and improving the quality of these green spaces by modifying their size [57] and/or shape to increase the core area and reduce edge effects [114], and by ecological restoration that creates structurally and compositionally diverse vegetation $[111,113]$ can promote diverse urban invertebrate communities. At the city scale, establishment of semi-natural habitat patches $[111,113]$, reconnecting of urban green spaces $[49,53,59]$, and a paradigm shift in urban planning [106] can assist to preserve and enhance not only carabids but urban biodiversity in general.

\section{Conclusions}

The available evidence confirms that urbanization has a substantial effect at all levels of biological organization on ground beetles living in urban green spaces. 
At the population level, changes in environmental and habitat parameters caused by urbanization enforce shifts in morphological characteristics of ground beetles, size variation, and body condition. However, direct evidence, e.g., by comparing fat reserves between individuals living in urban versus rural populations, is still missing. Urbanization may also have an impact on behavioral traits, such as exploration and risktaking. Environmental changes by urbanization (e.g., heat island effect, pollution) may be manifested in changes of seasonal activity and toxic element accumulation. Moreover, environmental changes can intensify the effects of habitat alteration (fragmentation, isolation, habitat deterioration), influencing the size and genetic diversity of urban populations. Population-level effects, however, show inconsistent patterns. This may result from different species responses, but also from differences in the urbanization gradients that are not rigorously defined or characterized. Thus, simultaneous population-level studies using the same methodology along identical, well-characterized urban gradients are essential.

Different sensitivity to urbanization may contribute to inconsistencies in the available population-level results. At the subcommunity/species group level, ground beetles show a consistent pattern along urbanization gradients: habitat specialist, large-sized, carnivorous species with limited dispersal power seem to suffer, while small-sized, omnivorous, or herbivorous, good disperser matrix species benefit from urbanization-induced changes in environmental and habitat conditions.

At the community level, the urbanization-driven changes constitute a strong environmental filter, enabling only species with traits and tolerance limits appropriate for urban environment to become members of the urban species pool. However, it is not guaranteed that these filtered species can permanently survive and maintain viable populations in urban habitats. This depends on the landscape configuration, management intensity, and their dispersal characteristics. At the same time, some habitat specialist species are also able to adapt to urban conditions and thus survive in urban habitats. These stochastic processes fundamentally determine the abundance, the taxonomic and functional diversity of the community. Currently, the functional approach is quite neglected in urban ground beetle ecology, so more studies are needed on this topic.

Of the ecosystem processes relevant for ground beetles, so far only edge effects and predation have been quantitatively studied. Other important processes, such as competition, the role of pathogens, or parasitism, remain unexplored. As urbanization also alters the species composition of spiders [115, 116], ants [69, 117], and rove beetles [81], which are strong competitors of ground beetles [26], studies on intraguild competition would be informative.

To preserve ground beetle diversity in urban areas, a holistic, multi-scale management at multiple (habitat, city, and landscape) scales is needed. At the habitat scale, conversion to ecologically oriented management aimed at improving habitat quality, at the city scale, establishing, reconnecting of urban green spaces, and compact city planning, while at the landscape scale, optimal landscape composition and configuration considering the dynamics of sources, corridors, and fragments can preserve and enhance the diversity of not only carabids but other organisms as well.

Acknowledgments The authors would like to thank Roland Horváth, Szabolcs Mizser, Dávid D. Nagy, and Béla Tóthmérész for discussions on the topic.

Authors' Contributions Planning, data collection: T.M.; data evaluation: T.M., G.L.L.; writing: T.M., G.L.L.

Funding Open access funding provided by University of Debrecen. This publication was supported by the National Research, Development and Innovation Fund (grant number OTKA K-131459).

\section{Compliance with Ethical Standards}

Conflict of Interest T.M. and G.L.L. have no conflicts of interests to declare.

Human and Animal Rights and Informed Consent This article contains no studies with human or animal subjects performed by the authors.

Open Access This article is licensed under a Creative Commons Attribution 4.0 International License, which permits use, sharing, adaptation, distribution and reproduction in any medium or format, as long as you give appropriate credit to the original author(s) and the source, provide a link to the Creative Commons licence, and indicate if changes were made. The images or other third party material in this article are included in the article's Creative Commons licence, unless indicated otherwise in a credit line to the material. If material is not included in the article's Creative Commons licence and your intended use is not permitted by statutory regulation or exceeds the permitted use, you will need to obtain permission directly from the copyright holder. To view a copy of this licence, visit http://creativecommons.org/licenses/by/4.0/.

\section{References}

Papers of particular interest, published recently, have been highlighted as:

- Of importance

•. Of major importance

1. Antrop M. Changing patterns in the urbanized countryside of Western Europe. Landsc Ecol. 2000;15:257-70.

2. McIntyre NE. Urban ecology — definitions and goals. In: Douglas I, Goode D, Houck M, Wang R, editors. The Routledge handbook of urban ecology. London: Routledge; 2011. p. 7-16.

3. United Nations. World urbanization prospects: the 2018 revision. New York: United Nations, Department of Economic and Social Affairs, Population Division; 2018. 
4. Wilson EO. The future of life. New York: Little, Brown \& Co; 2002.

5. Kalnay E, Cai M. Impact of urbanization and land-use change on climate. Nature. 2003;423:528-31.

6. Pouyat RV, McDonnell MJ, Pickett STA. Litter decomposition and nitrogen mineralization in oak stands along an urban-rural land use gradient. Urban Ecosyst. 1997;1:117-31.

7. Karl TR, Diaz HF, Kukla G. Urbanization: its detection and effect in the United States climate record. J Clim. 1988;1:1099-123.

8. Alcoforado MJ, Andrade H. Global warming and the urban heat island. In: Marzluff JM, Shulenberger E, Endlicher W, Alberti M, Bradley G, Ryan C, et al., editors. Urban ecology. New York: Springer; 2008.

9. Liu W, You H, Dou J. Urban-rural humidity and temperature differences in the Beijing area. Theor Appl Climatol. 2009;96: 201-7.

10. Pickett STA, Cadenasso ML, Grove JM, Nilon CH, Pouyat RV, Zipperer WC, et al. Urban ecological systems: linking terrestrial ecological, physical, and socioeconomic components of metropolitan areas. Annu Rev Ecol Syst. 2001;32:127-57.

11. Simon E, Harangi S, Baranyai E, Braun M, Fábián I, Mizser S, et al. Distribution of toxic elements between biotic and abiotic components of terrestrial ecosystem along an urbanization gradient: soil, leaf litter and ground beetles. Ecol Indic. 2016;60:25864.

12. McDonnell MJ, Pickett STA, Groffman P, Bohlen P, Pouyat RV, Zipperer WC, et al. Ecosystem processes along an urban-to-rural gradient. Urban Ecosyst. 1997;1:21-36.

13. Grimm NB, Faeth SH, Golubiewski NE, Redman CL, Wu J, Bai $\mathrm{X}$, et al. Global change and the ecology of cities. Science. 2008;319:756-60.

14. Kowarik I. Novel urban ecosystems, biodiversity, and conservation. Environ Pollut. 2011;159:1974-83.

15. Faeth SH, Bang C, Saari S. Urban biodiversity: patterns and mechanisms. Ann N Y Acad Sci. 2011;1223:69-81.

16. Desaegher J, Nadot S, Machon N, Colas B. How does urbanization affect the reproductive characteristics and ecological affinities of street plant communities? Ecol Evol. 2019;9:9977-89.

17. Chace JF, Walsh JJ. Urban effects on native avifauna: a review. Landsc Urban Plan. 2006;74:46-69.

18. Marzluff JM, Bowman R, Donnelly R. A historical perspective on urban bird research: trends, terms, and approaches. In: Marzluff JM, Bowman R, Donnelly R, editors. Avian ecology and conservation in an urbanizing world. New York: Kluwer Academic; 2001. p. 1-18.

19. Williams NSG, Hahs AK, Vesk PA. Urbanisation, plant traits and the composition of urban floras. Perspect Plant Ecol Evol Syst. 2015;17:78-86.

20. Singh AK, Singh H, Singh JS. Plant diversity in cities: call for assessment and conservation. Curr Sci. 2018;115:428-35.

21. McIntyre NE, Rango J, Fagan WF, Faeth SH. Ground arthropod community structure in a heterogeneous urban environment. Landsc Urban Plan. 2001;52:257-74.

22. Fenoglio MS, Rossetti MR, Videla M. Negative effects of urbanization on terrestrial arthropod communities: a meta-analysis. Glob Ecol Biogeogr. 2020;29:1412-1429. This study shows that urbanization has a negative effect on the diversity and abundance of terrestrial arthropods. Beetles are one of the most affected groups.

23. Kotze DJ, Brandmayr P, Casale A, Dauffy-Richard E, Dekoninck W, Koivula M, et al. Forty years of carabid beetle research in Europe - from taxonomy, biology, ecology and population studies to bioindication, habitat assessment and conservation. Zookeys. 2011;100:55-148.

24. Niemelä J, Kotze DJ. Carabid beetle assemblages along urban to rural gradients: a review. Landsc Urban Plan. 2009;92:65-71.
25. Martinson HM, Raupp MJ. A meta-analysis of the effects of urbanization on ground beetle communities. Ecosphere. 2013;4:60.

26. Lövei GL, Sunderland KD. Ecology and behavior of ground beetles (Coleoptera: Carabidae). Annu Rev Entomol. 1996;41:23156.

27. Koivula M. Useful model organisms, indicators, or both? Ground beetles (Coleoptera, Carabidae) reflecting environmental conditions. Zookeys. 2011;100:287-317.

28. Šustek Z. Changes in body size structure of carabid communities (Coleoptera, Carabidae) along an urbanisation gradient. Biológia (Bratislava). 1987;42:145-56.

29. Vanderbilt K, Gaiser E. The International Long Term Ecological Research Network: a platform for collaboration. Ecosphere. 2017;8:e1697.

30. Niemelä J, Kotze J, Ashworth A, Brandmayr P, Desender K, New $\mathrm{T}$, et al. The search for common anthropogenic impacts on biodiversity: a global network. J Insect Conserv. 2000;4:3-9.

31. Hudson LN, Newbold T, Contu S, Hill SLL, Lysenko I, De Palma A, et al. The database of the PREDICTS (projecting responses of ecological diversity in changing terrestrial systems) project. Ecol Evol. 2017;7:145-88.

32. Magura T, Lövei GL, Tóthmérész B. Does urbanization decrease diversity in ground beetle (Carabidae) assemblages? Glob Ecol Biogeogr. 2010;19:16-26.

33. Lagisz M. Changes in morphology of the ground beetle Pterostichus oblongopunctatus F. (Coleoptera; Carabidae) from vicinities of a zinc and lead smelter. Environ Toxicol Chem. 2008;27:1744-7.

34. Peters RH. The ecological implications of body size. Cambridge: Cambridge University Press; 1983.

35. Gray JS. Effects of environmental stress on species rich assemblages. Biol J Linn Soc. 1989;37:19-32.

36. Weller B, Ganzhorn JU. Carabid beetle community composition, body size, and fluctuating asymmetry along an urban-rural gradient. Basic Appl Ecol. 2004;5:193-201.

37. Sukhodolskaya RA, Saveliev AA. Effects of ecological factors on size-related traits in the ground beetle Carabus granulatus L. (Coleoptera, Carabidae). Russ J Ecol. 2014;45:414-20.

38. Sadler JP, Small EC, Fiszpan H, Telfer MG, Niemelä J. Investigating environmental variation and landscape characteristics of an urban-rural gradient using woodland carabid assemblages. J Biogeogr. 2006;33:1126-38.

39. Papp D, Mizser S, Nagy L, Vidic A, Simon E, Tóthmérész B. Changes in morphometric traits of ground beetles along urbanization gradients. J Insect Sci. 2020;20:5.

40. Brigić A, Starčević M, Hrašovec B, Elek Z. Old forest edges may promote the distribution of forest species in carabid assemblages (Coleoptera: Carabidae) in Croatian forests. Eur J Entomol. 2014;111:715-25.

41. Palmer AR, Strobeck C. Fluctuating asymmetry: measurement, analysis, patterns. Annu Rev Ecol Syst. 1986;17:391-421.

42. Floate KD, Fox AS. Flies under stress: a test of fluctuating asymmetry as a biomonitor of environmental quality. Ecol Appl. 2000;10:1541-50.

43. Elek Z, Lövei GL, Bátki M. No increase in fluctuating asymmetry in ground beetles (Carabidae) as urbanisation progresses. Community Ecol. 2014;15:131-8.

44. Elek Z, Lövei GL, Bátki M. Sex-specific interaction of body condition and asymmetry in carabids in distinct urbanisation stages. Community Ecol. 2017;18:253-9.

45. Mizser S, Nagy L, Tóthmérész B. Mite infection of Carabus violaceus in rural forest patches and urban parks. Period Biol. 2016;118:307-9.

46.• Schuett W, Delfs B, Haller R, Kruber S, Roolfs S, Timm D, et al. Ground beetles in city forests: does urbanization predict a personality trait? PeerJ. 2018;6:e4360 This study analyses the 
behavioural responses of ground beetles to urbanization. Results prove that individuals are generally more exploratory in more than in less urbanized areas. More exploratory individuals also take higher risks.

47. Elek Z, Howe A, Enggaard M, Lövei G. Seasonal dynamics of common ground beetles (Coleoptera: Carabidae) along an urbanisation gradient near Sorø, Zealand, Denmark. Entomol Fenn. 2017;28:27-40.

48. Lövei GL, Elek Z, Howe A, Engaard M. The use of percentilepercentile plots to compare differences in seasonal dynamics, illustrated by the case of ground beetles (Coleoptera, Carabidae) reacting to urbanisation. Community Ecol. 2018;19:1-8.

49. Vergnes A, Chantepie S, Robert A, Clergeau P. Are urban green spaces suitable for woodland carabids? First insights from a shortterm experiment. J Insect Conserv. 2013;17:671-9.

50. Noreika N, Pajunen T, Kotze DJ. Urban mires as hotspots of epigaeic arthropod diversity. Biodivers Conserv. 2015;24:29913007.

51. Magura T, Tóthmérész B, Molnár T. A species-level comparison of occurrence patterns in carabids along an urbanisation gradient. Landsc Urban Plan. 2008;86:134-40.

52. Belskaya E, Zolotarev M, Zinovyev E. Carabidae assemblages in pine forests with different recreation regimes within and outside a megalopolis. Urban Ecosyst. 2020;23:27-38.

53. Buchholz S, Hannig K, Möller M, Schirmel J. Reducing management intensity and isolation as promising tools to enhance grounddwelling arthropod diversity in urban grasslands. Urban Ecosyst. 2018;21:1139-49.

54. Desender K. Theory versus reality: a review on the ecological and population genetic effects of forest fragmentation on wild organisms, with an emphasis on ground beetles. DIAS Rep. 2005;114: 49-72.

55. Desender K, Small E, Gaublomme E, Verdyck P. Rural-urban gradients and the population genetic structure of woodland ground beetles. Conserv Genet. 2005;6:51-62.

56. Gagné SA, Fahrig L. Do birds and beetles show similar responses to urbanization? Ecol Appl. 2011;21:2297-312.

57. Gaublomme E, Hendrickx F, Dhuyvetter H, Desender K. The effects of forest patch size and matrix type on changes in carabid beetle assemblages in an urbanized landscape. Biol Conserv. 2008;141:2585-96.

58. Magura T, Lövei GL, Tóthmérész B. Time-consistent rearrangement of carabid beetle assemblages by an urbanisation gradient in Hungary. Acta Oecol. 2008;34:233-43.

59. Hartley JD, Koivula JM, Spence RJ, Pelletier R, Ball EG. Effects of urbanization on ground beetle assemblages (Coleoptera, Carabidae) of grassland habitats in western Canada. Ecography. 2007;30:673-84.

60. Alaruikka D, Kotze DJ, Matveinen K, Niemelä J. Carabid beetle and spider assemblages along a forested urban-rural gradient in southern Finland. J Insect Conserv. 2002;6:195-206.

61. Varet M, Pétillon J, Burel F. Comparative responses of spider and carabid beetle assemblages along an urban-rural boundary gradient. J Arachnol. 2011;39:236-43.

62. Kotze DJ, O'Hara RB. Species decline - but why? Explanations of carabid beetle (Coleoptera, Carabidae) declines in Europe. Oecologia. 2003;135:138-48.

63. Elek Z, Lövei GL. Patterns in ground beetle (Coleoptera: Carabidae) assemblages along an urbanisation gradient in Denmark. Acta Oecol. 2007;32:104-11.

64. Magura T, Tóthmérész B, Lövei GL. Body size inequality of carabids along an urbanisation gradient. Basic Appl Ecol. 2006;7:472-82.

65. Castro AV, Porrini DP, Lupo S, Cicchino AC. Minimal stories in Southeast Buenos Aires grasslands: carabid beetle biodiversity throughout an urban-rural gradient. Urban Ecosyst. 2020;23: 331-43.

66. Šustek Z. Changes in the representation of carabid life forms along an urbanization gradient (Coleoptera, Carabidae). Biologia (Bratisl). 1992;47:417-30.

67. Ishitani M, Kotze DJ, Niemelä J. Changes in carabid beetle assemblages across an urban-rural gradient in Japan. Ecography. 2003;26:481-9.

68. Venn JS, Kotze D, Niemelä J. Urbanization effects on carabid diversity in boreal forests. Eur J Entomol. 2003;100:73-80.

69. Penev L, Stoyanov I, Dedov I, Antonova V. Patterns of urbanisation in the City of Sofia as shown by carabid beetles (Coleoptera, Carabidae), ants (Hymenoptera, Formicidae), and terrestrial gastropods (Mollusca, Gastropoda Terrestria). In: Penev L, Erwin T, Assmann T, editors. Back to the roots or back to the future? Towards a new synthesis between taxonomic, ecological \& biogeographical approaches in carabidology. Sofia: Pensoft Publishers; 2008. p. 483-509.

70. Magura T, Tóthmérész B, Molnár T. Changes in carabid beetle assemblages along an urbanisation gradient in the city of Debrecen, Hungary. Landsc Ecol. 2004;19:747-59.

71. Lövei GL, Liu WX, Guo JY, Wan FH. The use of the Rényi scalable diversity index to assess diversity trends in comparative and monitoring studies of effects of transgenic crops. J Biosaf. 2013;22:43-50.

72. Connell JH. Diversity in tropical rain forests and coral reefs. Science. 1978;199:1302-10.

73. Tóthmérész B, Máthé I, Balázs E, Magura T. Responses of carabid beetles to urbanization in Transylvania (Romania). Landsc Urban Plan. 2011;101:330-7.

74. Vergnes A, Pellissier V, Lemperiere G, Rollard C, Clergeau P. Urban densification causes the decline of ground-dwelling arthropods. Biodivers Conserv. 2014;23:1859-77.

75. Niemelä J, Kotze DJ, Venn S, Penev L, Stoyanov I, Spence J, et al. Carabid beetle assemblages (Coleoptera, Carabidae) across urban-rural gradients: an international comparison. Landsc Ecol. 2002; 17:387-401.

76. Zolotarev MP, Belskaya EA. Ground-dwelling invertebrates in a large industrial city: differentiation of recreation and urbanization effects. Contemp Probl Ecol. 2015;8:83-90.

77. Knapp S, Kühn I, Mosbrugger V, Klotz S. Do protected areas in urban and rural landscapes differ in species diversity? Biodivers Conserv. 2008; 17:1595-612.

78. Croci S, Butet A, Georges A, Aguejdad R, Clergeau P. Small urban woodlands as biodiversity conservation hot-spot: a multitaxon approach. Landsc Ecol. 2008;23:1171-86.

79. Sapia M, Lövei G, Elek Z. Effects of varying sampling effort on the observed diversity of carabid (Coleoptera: Carabidae) assemblages in the Danglobe project. Denmark Entomol Fenn. 2006;17: 345-50.

80. Cadotte M, Albert CH, Walker SC. The ecology of differences: assessing community assembly with trait and evolutionary distances. Ecol Lett. 2013;16:1234-44.

81. Nagy DD, Magura T, Horváth R, Debnár Z, Tóthmérész B. Arthropod assemblages and functional responses along an urbanization gradient: a trait-based multi-taxa approach. Urban For Urban Green. 2018;30:157-68.

82.• Fournier B, Frey D, Moretti M. The origin of urban communities: from the regional species pool to community assemblages in city. J Biogeogr. 2020;47:615-29 The authors investigate the ecological mechanisms shaping urban community assembly. Their results show that the studied city selects for functionally similar but taxonomically diverse ground beetle species from the regional species pool.

83.• Magura T, Lövei GL, Tóthmérész B. Conversion from environmental filtering to randomness as assembly rule of ground beetle 
assemblages along an urbanization gradient. Sci Rep. 2018;8: 16992 This study, simultaneously evaluating the functional and phylogenetic relationships of co-existing species, shows that environmental filtering is the likely process structuring rural ground beetle communities, while urban communities are randomly structured.

84. Piano E, De Wolf K, Bona F, Bonte D, Bowler DE, Isaia M, et al. Urbanization drives community shifts towards thermophilic and dispersive species at local and landscape scales. Glob Chang Biol. 2017;23:2554-64 This study demonstrates that urbanization alters species composition of ground beetles by filtering for species with a preference for higher temperatures and better dispersal capacities.

85. Do Y, Lineman M, Joo G-J. Carabid beetles in green infrastructures: the importance of management practices for improving the biodiversity in a metropolitan city. Urban Ecosyst. 2014;17:66173.

86. Varet M, Burel F, Lafage D, Pétillon J. Age-dependent colonization of urban habitats: a diachronic approach using carabid beetles and spiders. Anim Biol. 2013;63:257-69.

87. Kotze DJ, Lehvävirta S, Koivula M, O'Hara RB, Spence JR. Effects of habitat edges and trampling on the distribution of ground beetles (Coleoptera, Carabidae) in urban forests. J Insect Conserv. 2012;16:883-97.

88. Sattler T, Obrist MK, Duelli P, Moretti M. Urban arthropod communities: added value or just a blend of surrounding biodiversity? Landsc Urban Plan. 2011;103:347-61.

89. Fujita A, Maeto K, Kagawa Y, Ito N. Effects of forest fragmentation on species richness and composition of ground beetles (Coleoptera: Carabidae and Brachinidae) in urban landscapes. Entomol Sci. 2008;11:39-48.

90. Merckx T, Souffreau C, Kaiser A, Baardsen LF, Backeljau T, Bonte $\mathrm{D}$, et al. Body-size shifts in aquatic and terrestrial urban communities. Nature. 2018;558:113-6 This study shows that the increased temperature in urban habitats (the urban-heatisland effect) causes community-wide shifts towards species with smaller body sizes in urban ground beetle communities due to increased metabolic costs.

91. Gaublomme E, Dhuyvetter H, Verdyck P, Desender K. Effects of urbanisation on carabid beetles in old beech forests. DIAS Rep. 2005;114:111-23.

92. Schaefer M, Kock K. Zur Ökologie der Arthropodenfauna einer Stadtlandschaft und ihrer Umgebung. Anzeiger für Schädlingskunde, Pflanzenschutz, Umweltschutz. 1979;52:8590.

93. Czechowski W. Influence of the manner of managing park areas and their situation on the formation of the communities of carabid beetles (Coleoptera: Carabidae). Fragm Faun. 1980;25:199-219.

94. Magura T, Ferrante M, Lövei GL. Only habitat specialists become smaller with advancing urbanisation. Glob Ecol Biogeogr. 2020;29:in press. The authors detect no general trend toward a reduced community-level body size in urban habitats with increased temperature by the total community, but the subassemblages of habitat specialist species consistently displayed a shift toward smaller size in urban habitats with respect to rural ones.

95. Murcia C. Edge effects in fragmented forests: implications for conservation. Trends Ecol Evol. 1995;10:58-62.

96. Davis DE, Gagné SA. Boundaries in ground beetle (Coleoptera: Carabidae) and environmental variables at the edges of forest patches with residential developments. PeerJ. 2018;6:e4226.

97. Magura T, Lövei GL, Tóthmérész B. Edge responses are different in edges under natural versus anthropogenic influence: a metaanalysis using ground beetles. Ecol Evol. 2017;7:1009-17.

98. Magura T, Lövei GL. The permeability of natural versus anthropogenic forest edges modulates the abundance of ground beetles of different dispersal power and habitat affinity. Diversity. 2020;12:320.

99. Magura T, Lövei GL, Tóthmérész B. Various edge response of ground beetles in edges under natural versus anthropogenic influence: a meta-analysis using life-history traits. Acta Zool Acad Sci Hungaricae. 2019;65:3-20.

100. Shochat E, Warren PS, Faeth SH, McIntyre NE, Hope D. From patterns to emerging processes in mechanistic urban ecology. Trends Ecol Evol. 2006;21:186-91.

101. Eötvös CB, Magura T, Lövei GL. A meta-analysis indicates reduced predation pressure with increasing urbanization. Landsc Urban Plan. 2018;180:54-9.

102. Ferrante M, Lo Cacciato A, Lövei GL. Quantifying predation pressure along an urbanisation gradient in Denmark using artificial caterpillars. Eur J Entomol. 2014;111:649-54.

103. Eötvös CB, Lövei GL, Magura T. Predation pressure on sentinel insect prey along a riverside urbanization gradient in Hungary. Insects. 2020;11:97.

104. Bohan DA, Boursault A, Brooks DR, Petit S. National-scale regulation of the weed seedbank by carabid predators. J Appl Ecol. 2011;48:888-98

105. von Berg K, Traugott M, Scheu S. Scavenging and active predation in generalist predators: a mesocosm study employing DNAbased gut content analysis. Pedobiologia. 2012;55:1-5.

106. Norton BA, Evans KL, Warren PH. Urban biodiversity and landscape ecology: patterns, processes and planning. Curr Landsc Ecol Reports. 2016;1:178-92.

107. New TR. Insect conservation and urban environments. New York: Springer; 2015.

108. Varet M, Burel F, Pétillon J. Can urban consolidation limit local biodiversity erosion? Responses from carabid beetle and spider assemblages in Western France. Urban Ecosyst. 2014;17:123-37.

109. Gagné SA, Fahrig L. The trade-off between housing density and sprawl area: minimizing impacts to carabid beetles (Coleoptera: Carabidae). Ecol Soc. 2010;15:12.

110. Arroyo-Rodríguez V, Fahrig L, Tabarelli M, Watling JI, Tischendorf L, Benchimol M, et al. Designing optimal humanmodified landscapes for forest biodiversity conservation. Ecol Lett. 2020;23:1404-1420

111. Soga M, Yamaura Y, Koike S, Gaston KJ. Woodland remnants as an urban wildlife refuge: a cross-taxonomic assessment. Biodivers Conserv. 2014;23:649-59.

112. Vergnes A, Le Viol I, Clergeau P. Green corridors in urban landscapes affect the arthropod communities of domestic gardens. Biol Conserv. 2012;145:171-8.

113. Venn SJ, Kotze DJ, Lassila T, Niemelä JK. Urban dry meadows provide valuable habitat for granivorous and xerophylic carabid beetles. J Insect Conserv. 2013;17:747-64.

114. Soga M, Kanno N, Yamaura Y, Koike S. Patch size determines the strength of edge effects on carabid beetle assemblages in urban remnant forests. J Insect Conserv. 2013;17:421-8.

115. Lövei GL, Horváth R, Elek Z, Magura T. Diversity and assemblage filtering in ground-dwelling spiders (Araneae) along an urbanisation gradient in Denmark. Urban Ecosyst. 2019;22:345-53.

116. Magura T, Horváth R, Tóthmérész B. Effects of urbanization on ground-dwelling spiders in forest patches, in Hungary. Landsc Ecol 2010;25.

117. Melliger RL, Braschler B, Rusterholz HP, Baur B. Diverse effects of degree of urbanisation and forest size on species richness and functional diversity of plants, and ground surface-active ants and spiders. PLoS One. 2018;13:e0199245.

Publisher's Note Springer Nature remains neutral with regard to jurisdictional claims in published maps and institutional affiliations. 